\title{
Emerged fossil corals on the coast of northwestern Hainan Island, China: Implications for mid-Holocene sea level change and tectonic uplift
}

\author{
YAO YanTao*, ZHAN WenHuan, SUN JinLong \& SUN Jie \\ CAS Key Laboratory of Marginal Sea Geology, South China Sea Institute of Oceanology, Chinese Academy of Sciences (CAS), \\ Guangzhou 510301, China
}

Received August 13, 2012; accepted September 28, 2012; published online March 1, 2013

\begin{abstract}
Fossil corals are widespread on the coast of northwestern Hainan Island, China. Most of these corals are exposed during low tide levels, indicating that a higher sea level may have existed during their life time. The radiocarbon data introduced by this paper in combination with those from other sources show that the corals were alive mainly during the mid- to late-Holocene. Mid-Holocene sea levels 1-3 m higher than the present level were confirmed for adjacent coasts; however, the emerged corals on the investigated coast are not necessarily indicators of a higher eustatic sea level. They do predict relative sea levels of 1.5-3.4 m when using $1 \mathrm{~m}$ below the tidal datum as the upper limit of coral growth. However, using the Mean Lower Low Water as the coral's upper growth limit, the relative sea level on the non-volcanic coast was almost as high as the present level, whereas that on the volcanic coast was 0.4-2.0 m higher than present. Therefore, the exposure of these dead coral heads and their discrepancy in elevation may be the result of tectonic uplift caused by volcanic activities. From these results, the highest sea level of upward coral growth must be defined first when using fossil corals to reconstruct past sea levels. Meanwhile, vertical tectonics have to be taken into account as a significant factor when conducting high-resolution sea level reconstruction, although the South China coast is located in a "tectonically stable" region.
\end{abstract}

fossil coral, higher sea level, tectonic uplift, mid-Holocene, coast of northwestern Hainan Island

Citation: Yao Y T, Zhan W H, Sun J L, et al. Emerged fossil corals on the coast of northwestern Hainan Island, China: Implications for mid-Holocene sea level change and tectonic uplift. Chin Sci Bull, 2013, 58: 2869-2876, doi: 10.1007/s11434-013-5692-7

Corals have the highest level of survival, which depends mostly on their exposure to air during low tide levels [1]. That is to say levels of survival are essentially controlled by sea level, which is why fossil corals have been widely used as proxies for sea level [2-6]; in particular, microatolls are considered one of the most reliable indicators [7]. Reef flats, commonly formed by the dead top surfaces of large massive in-situ massive Porites in shallow waters, may also accurately record a paleo sea level [8]. As a result, combining fossil corals with proper dating methods has become an important source of information about paleo sea levels. Especially in the tropical shallow water regions, coral reefs can be regarded as the most effective tool for reconstructing high-resolution sea level curves.

*Corresponding author (email: yaoyt@scsio.ac.cn)
Because coral growth is greatly controlled by water depth, vertical crustal movements causing relative sea level changes must indirectly influence the development of corals or coral reefs; and vice versa, coral records of relative sea level changes may contain tectonic information. Therefore, coral reefs have also been deployed for studies of vertical crustal movements [9-12].

Whether the sea level was higher at the South China coast during the mid-Holocene used to be controversially debated. Research techniques and experimental devices have greatly improved, and high-resolution and high-precision data were published during the last few years [13-16]. As a result, the history of sea level fluctuations for the South China coast became better understood [17,18], and the argument for a higher mid-Holocene sea level based on emerged coral heads has become gradually accepted. For example, a mid- 
Holocene sea level 1-3 m higher than present was confirmed for the Leizhou Peninsula [13,19,20], Sanya [16,21], and Qionghai [22] by investigating fossil corals. However, all these results were based on the assumption of a stable crust.

Coral reefs on the northwest coast of Hainan Island are well developed, and most of the coral heads on the reef flat that died in-situ are exposed to the atmosphere at low spring tide. From our field investigation, we found that the elevations of these emerged corals varied apparently between different sections of the coast. The question is whether these emerged coral heads indicate a higher sea level during the mid-Holocene? In such a local area of investigation, could the differences in elevations be the result of crustal differential uplift? If so, can inconspicuously vertical movements of the "stable crust" continue to be neglected when carrying out high-resolution reconstruction of sea levels for the South China coast? To answer these questions, this paper focuses on emerged coral heads along the northwest coast of Hainan Island. This study aims to demonstrate the variability of the mid-Holocene sea level at different coasts and, furthermore, to prove that the influence of vertical crustal movements on sea level change can not be disregarded when reconstructing Holocene sea levels in this area.

\section{Materials and methods}

\subsection{Study site}

Hainan Island is situated on the northern passive continental margin of the South China Sea (Figure 1), the intersection of the Eurasian, Pacific and Indian plates, and also the eastward extension of the Red River suture zone. Influenced by the spreading of the South China Sea basin and the compression of the Philippine Sea plate into the Indian plate, three groups of faults have been developed in Hainan Island trending E-W, NE, and NW. In the northern Hainan Island, the NW group is the most active and the fault to which most volcanoes are bound. During the Quaternary, the Leizhou Peninsular and northern Hainan Island went through a stage of strong volcanic activities, resulting in the largest basaltic area in South China, which is $7000 \mathrm{~km}^{2}$ [24]. During this active stage, the north coast of Hainan Island was distinctly uplifted. For example, an outcrop of the pre-Holocene marine sediments at Shenjian indicates that the coast was up-

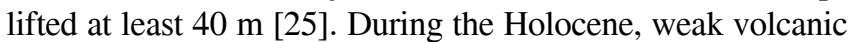
activities continued, and small volcanoes developed along some coastal faults [26], causing slight local crust uplift.

Since the Quaternary, as the climate frequently changed, alternating between cold and warm periods, Hainan Island experienced sea level fluctuations and coastline changes accordingly. During the Last Glacial Maximum, the sea level was more than $100 \mathrm{~m}$ lower than at present, and the Beibu Gulf was wholly emerged as mainland [27]. Due to the rising sea level in the Holocene and a suitable environment for coral growth, fringing reefs were extensively developed around Hainan Island. The study area of this paper is one section of the coast with well-developed coral reefs. In this small area, Quaternary volcanic activities resulted in
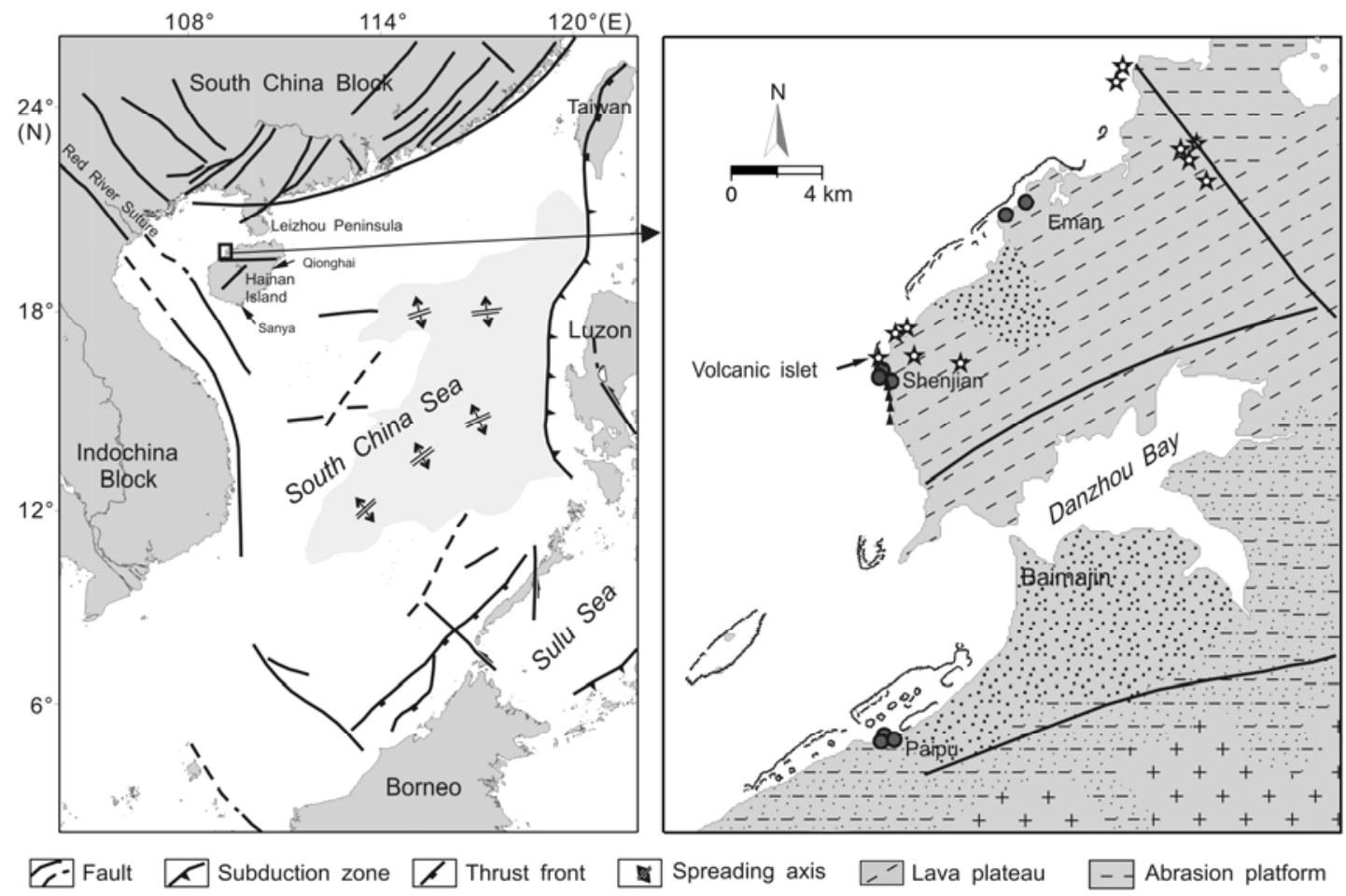

Abrasion plateau $\because$ : Marine plain $\because$ Alluvia plain $\square$ Beachrock $\square$ Crater $\square$ Coral reef Sampling site

Figure 1 Maps showing the geological setting [23] of the studied area and locations of the AMS ${ }^{14} \mathrm{C}$ coral samples. 
a peculiar geology. With the Danzhou Bay as a boundary, the study area can be divided into two zones greatly different in geological settings. The northern zone belongs to a basalt platform, whereas the southern zone is an alluvial plain (Figure 1). Different geological processes may be the major factor that caused corals from the north and the south to exhibit different features. Based on our field inspection in 2007-2008, in-situ massive coral heads sporadically distributed on the reef flat at Paipu emerged 0.2-0.5 m during low tide (Figure 2(a)). They were relatively well preserved and had diameters of 1-3 m. In comparison to the southern zone, fossil corals from Yangpu to Eman grew almost exclusively on basalts or volcanic breccias. Moreover, most of the coral heads had been heavily eroded (Figure 2(b) and (c)), with reef diameters ranging from only 0.5 to $2 \mathrm{~m}$, but, emerged heights of 0.5 to $1 \mathrm{~m}$. In particular, massive dead Porites, which were well preserved with discoid flat tops on the volcanic islet of Shenjian, were 1-2 m above low tide level (Figure 2(d)).

In recent years, studies on coral reefs of Hainan Island have mainly focused on the east and south coasts and on the topics of reef development, paleoclimatology, and paleoceanography [21,28-33]. By contrast, little attention has been paid to coral reefs on the northwest coast. Relevant results were last published before 1991 [34-38]. Although research techniques, experimental devices and precision have improved greatly, no new reports concerning the coral reefs of the northwest coast have been issued. As a result, the reef development, sea level changes and tectonics recorded by fossil corals in the study area are still poorly understood.

\subsection{Sampling}

Based on the growth characteristics of reef-building corals, relative sea level heights recorded in a dead coral surface can be accurately reconstructed with respect to the age and elevation of the dead surface. Differences in relative sea level heights between adjacent localities at a given time commonly result from vertical tectonic movement, so the rate of vertical crustal displacement can be calculated by comparing the elevations of coral surfaces that died at the same age. Following this principle, we took samples from the emerged coral heads at Paipu, Shenjian and Eman and leveled the elevations of their top surfaces.

To enhance the accuracy of our data, all the sampled corals were required to be massive in-situ Porites with diameters larger than $1 \mathrm{~m}$. In addition, only the corals with top surfaces near the reef top of the sampling site in elevation were selected. Among the 16 samples we took, 10 fresher and purer ones were picked for AMS ${ }^{14} \mathrm{C}$ dating. The locations of these dated corals are shown in Figure 1, and their detailed information is listed in Table 1.

In particular, we believed that the fossil corals on the Shenjian islet, which were exposed much higher than those at adjacent sites, may have had special implications for tectonics, so we took four samples, numbered SJ-005-1,

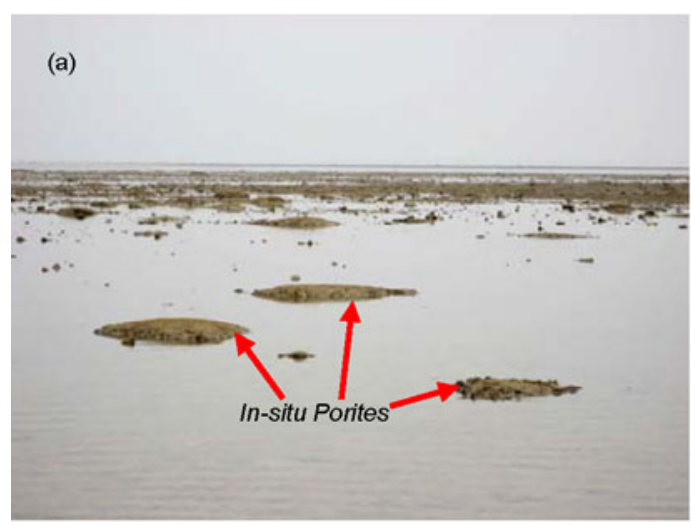

(c)

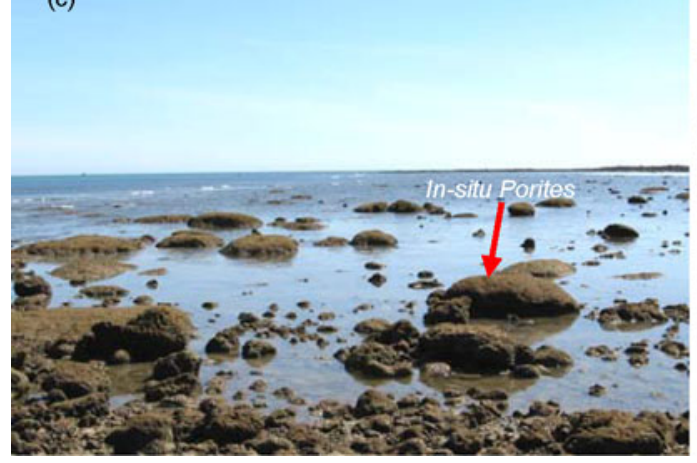

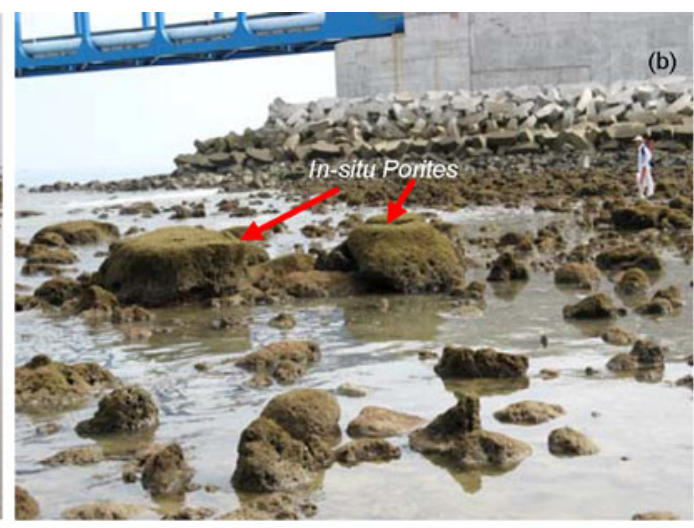

(d)

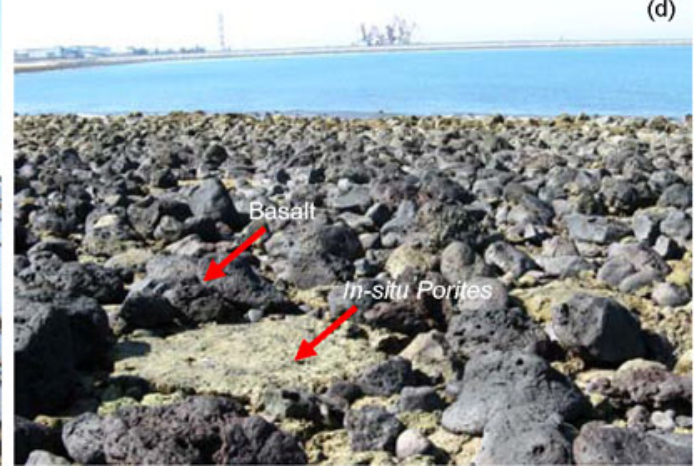

Figure 2 Fossil corals exposed on the coasts of Paipu (a), Shenjian (b), Eman(c) and the residual islet near Shenjian (d). 
Table 1 Information of samples for radiocarbon dating

\begin{tabular}{|c|c|c|c|c|c|c|}
\hline \multirow{2}{*}{ Site } & \multirow{2}{*}{ Sample No. } & \multicolumn{2}{|c|}{ Location } & \multirow{2}{*}{ Material } & \multirow{2}{*}{ Tide gauge station } & \multirow{2}{*}{ Elevation $^{\text {a) }}(\mathrm{m})$} \\
\hline & & Longitude & Latitude & & & \\
\hline Paipu & PP-001 & $109^{\circ} 09.482^{\prime} \mathrm{E}$ & $19^{\circ} 38.788^{\prime} \mathrm{N}$ & In-situ Porites & Baimajin & 0.66 \\
\hline Paipu & PP-002 & $109^{\circ} 09.399^{\prime} \mathrm{E}$ & $19^{\circ} 38.642^{\prime} \mathrm{N}$ & In-situ Porites & Baimajin & 0.59 \\
\hline Paipu & PP-004 & $109^{\circ} 09.717^{\prime} \mathrm{E}$ & $19^{\circ} 38.696^{\prime} \mathrm{N}$ & In-situ Porites & Baimajin & 0.68 \\
\hline Shenjian & SJ-004 & $109^{\circ} 09.668^{\prime} \mathrm{E}$ & $19^{\circ} 46.816^{\prime} \mathrm{N}$ & In-situ Porites & Yangpu & 1.30 \\
\hline Shenjian & SJ-005-1 & $109^{\circ} 09.433^{\prime} \mathrm{E}$ & $19^{\circ} 47.058^{\prime} \mathrm{N}$ & In-situ Porites & Yangpu & 2.40 \\
\hline Shenjian & $\mathrm{SJ}-005-2$ & $109^{\circ} 09.433^{\prime} \mathrm{E}$ & $19^{\circ} 47.058^{\prime} \mathrm{N}$ & In-situ Porites & Yangpu & 2.40 \\
\hline Shenjian & SJ-006-1 & $109^{\circ} 09.432^{\prime} \mathrm{E}$ & $19^{\circ} 47.061^{\prime} \mathrm{N}$ & In-situ Porites & Yangpu & 2.26 \\
\hline Shenjian & SJ-006-2 & $109^{\circ} 09.432^{\prime} \mathrm{E}$ & $19^{\circ} 47.061^{\prime} \mathrm{N}$ & In-situ Porites & Yangpu & 2.26 \\
\hline Eman & NT-001 & $109^{\circ} 12.390^{\prime} \mathrm{E}$ & $19^{\circ} 50.582^{\prime} \mathrm{N}$ & In-situ Porites & Yangpu & 0.87 \\
\hline Eman & NT-002 & $109^{\circ} 12.863^{\prime} \mathrm{E}$ & $19^{\circ} 50.875^{\prime} \mathrm{N}$ & In-situ Porites & Yangpu & 0.96 \\
\hline
\end{tabular}

a) Elevation relative to tidal datum.

SJ-005-2, SJ-006-1, and SJ-006-2, respectively, from two well-preserved microatolls (two samples from each coral head) for radiocarbon dating. By such means, not only could more precise ages for the two corals be found, but also the reliability of the dating results could be tested.

Relative sea level heights can be estimated from a dead coral surface by using the elevation of the dead surface relative to the low spring tide or relative to the highest level of survival of modern living corals $[8,19]$. Considering that the massive living Porites in the study area mainly grew on the outer reef flat or reef slope, we only measured the height of a dead coral top relative to the sea surface of the time of measuring. Then, the elevation of the dead coral top could be determined by comparing the leveling height with tidal ranges of nearby tide gauges. For this procedure on the non-volcanic coast, tide gauge data were taken from the Baimajin station. On the volcanic coast, we referred to tide gauge data from the Yangpu station. For the calculation, the present-day tidal datum was used as the base level. Eleva- tions of the dated samples relative to the base level are listed in Table 1.

\subsection{Radiocarbon dating}

The 10 coral samples for dating were sent to the State Key Laboratory of Loess and Quaternary Geology, where radiocarbon ages were achieved using accelerator mass spectrometry. The obtained age data are shown in Table 2. Before using the data, all the ${ }^{14} \mathrm{C}$ ages were converted to calendar years using the program Calib5.0.1 (http://www.calib. qub.ac.uk). As fossil corals are marine sediments, the percentage of marine carbon for the 10 dated samples was set at $100 \%$. The difference in reservoir age between the study area and the "global" ocean was determined from the marine reservoir correction database (http://www.calib.qub.ac.uk/ marine), which was the average of these values in sites 406 , 407, and 408 of Xisha.

Table 3 lists some data about coral ages, elevations and

Table $2 \mathrm{AMS}^{14} \mathrm{C}$ data for in-situ Porites from the coast of northwestern Hainan Island

\begin{tabular}{|c|c|c|c|c|c|c|c|c|}
\hline \multirow{2}{*}{ Sample } & \multicolumn{2}{|c|}{$\delta^{13} \mathrm{C}(\% \circ)$} & \multicolumn{2}{|c|}{$\mathrm{pMC}(\%)$} & \multicolumn{2}{|c|}{${ }^{14} \mathrm{C}$ age (a BP) } & \multicolumn{2}{|c|}{ Calibrated age $^{\text {a) }}$ (cal. a BP) } \\
\hline & $\delta^{13} \mathrm{C}$ & Error $(1 \sigma)$ & $\mathrm{pMC}$ & Error $(1 \sigma)$ & ${ }^{14} \mathrm{C}$ age & Error $(1 \sigma)$ & ${ }^{14} \mathrm{C}$ age & Error $(2 \sigma)$ \\
\hline PP-001 & -0.24 & 0.55 & 55.10 & 0.18 & 4788 & 26 & 5029 & 86 \\
\hline PP-002 & -4.16 & 0.38 & 56.91 & 0.17 & 4528 & 24 & 4713 & 83 \\
\hline PP-004 & -2.90 & 0.45 & 57.10 & 0.16 & 4502 & 22 & 4682 & 81 \\
\hline SJ-004 & -2.71 & 0.48 & 49.44 & 0.16 & 5658 & 25 & 6043 & 84 \\
\hline SJ-005-1 & -1.83 & 0.65 & 49.43 & 0.16 & 5661 & 25 & 6046 & 84 \\
\hline SJ-005-2 & -3.29 & 0.58 & 49.39 & 0.16 & 5667 & 25 & 6053 & 84 \\
\hline SJ-006-1 & -1.28 & 0.63 & 50.21 & 0.16 & 5534 & 25 & 5901 & 84 \\
\hline SJ-006-2 & -2.58 & 0.56 & 50.41 & 0.16 & 5503 & 26 & 5865 & 86 \\
\hline NT-001 & 0.59 & 0.40 & 53.34 & 0.17 & 5048 & 25 & 5381 & 84 \\
\hline NT-002 & -1.40 & 0.40 & 56.81 & 0.17 & 4543 & 24 & 4729 & 83 \\
\hline
\end{tabular}

a) Age calibrated using CALIB (Version5.0.1). 
Table $3{ }^{14} \mathrm{C}$ ages of in-situ corals gathered from other sources

\begin{tabular}{clccccc}
\hline Site & Material & ${ }^{14} \mathrm{C}$ age $($ a BP $)$ & Original elevation $(\mathrm{m})$ & Elevation $^{\text {a) }}(\mathrm{m})$ & Calibrated age $^{\text {b) }}(\mathrm{cal}$. a BP $)$ & Source \\
\hline Paipu & In-situ Porites & $5340 \pm 160$ & 0 & $0.66 \pm 0.08$ & $5696 \pm 164$ & {$[36]$} \\
Paipu & In-situ Porites & $4720 \pm 140$ & 0 & $0.66 \pm 0.08$ & $4963 \pm 144$ & {$[36]$} \\
Paipu & In-situ coral & $4510 \pm 110$ & 0 & $0.66 \pm 0.08$ & $4671 \pm 115$ & {$[36]$} \\
Paipu & In-situ coral & $4007 \pm 150$ & 0.2 & $0.66 \pm 0.08$ & $4003 \pm 154$ & {$[35]$} \\
Paipu & In-situ coral & $3542 \pm 123$ & 0 & $0.66 \pm 0.08$ & $3415 \pm 123$ & {$[36]$} \\
Paipu & In-situ coral & $3260 \pm 90$ & 0 & $0.66 \pm 0.08$ & $3006 \pm 96$ & {$[35]$} \\
\hline
\end{tabular}

a) Average elevation of emerged corals at Paipu relative to tidal datum; b) age calibrated using CALIB (Version5.0.1).

relevant information gathered from other previous publications. All the listed coral samples were collected at the nonvolcanic coast; for the volcanic coast, no valid data are available. To make comparisons, the original ${ }^{14} \mathrm{C}$ datings had to be calibrated to calendar years. Another problem is that the elevation data from previous publications were expressed in terms of altitude without providing any datum plane. According to our leveling data of 8 coral upper surfaces, the in situ coral heads on the coast from Paipu to Baimajin exhibited no significant difference in emerged height $(\leqslant 0.15 \mathrm{~m})$, so, we used the average elevation of the 8 coral tops, $0.66 \mathrm{~m}$, as the elevations of the previously published coral samples.

\subsection{Results}

Based on an age comparison of SJ-005-1, SJ-005-2, SJ-006-1 and SJ-006-2, the radiocarbon dating result was considered to be of reliable accuracy. According to the age data obtained in this paper and those collected from other papers, the life time of massive dead corals along the northwest coast of Hainan Island was estimated to be 6.0-3.0 cal. ka BP. At Paipu, three samples had younger ages of 4.0-3.0 cal. ka BP, and the other six were dated between 5.7-4.5 cal. ka BP. The three coral samples from Shenjian were dated around 6.0 cal. ka BP, and the two from Eman were dated at 4.7 cal. ka BP and 5.4 cal. ka BP. Therefore, the massive dead Porites in this area mostly grew in the middle Holocene, indicating that the middle Holocene was a period of prosperity for Porites, basically coinciding with the coral bloom or reef-formation stage of adjacent coasts, such as Sanyan in the south [21,28], Qionghai in the east [22], and Leizhou peninsular in the north $[19,39]$.

Figure 3 shows the plot of the coral age-elevation distribution. It illustrates that fossil corals from the three sampling sites have nearly the same ages. However, in terms of elevation, there were obvious deviations, which were confirmed by our field observations. First, at Paipu, where only a small part of the dead coral heads were exposed during low tide, coral elevations were approximately $0.6 \mathrm{~m}$. Secondly, at Eman, the representative elevation for corals was approximately $0.9 \mathrm{~m}$. Last, at Shenjian, where the corals were more emerged than those at Paipu and Eman, most of

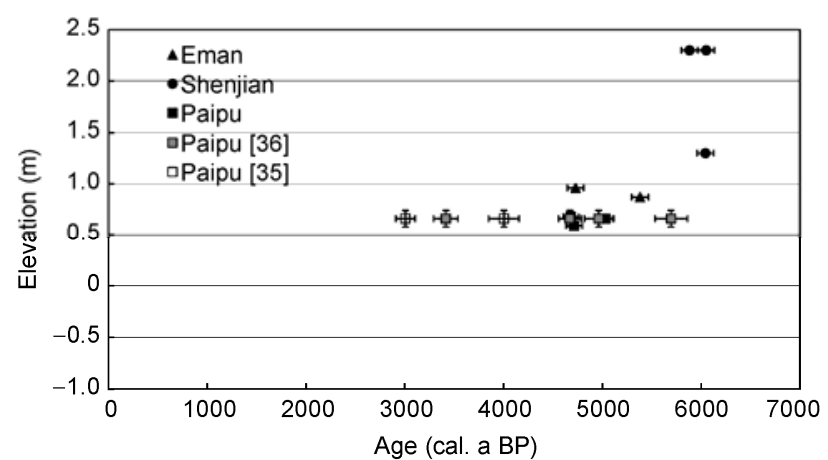

Figure 3 Plot of radiocarbon ages against elevations of in-situ fossil corals.

the dead coral heads had elevations around $1.3 \mathrm{~m}$, and particularly in the volcanic islet near Shenjian, the elevations of the in-situ coral heads were up to $2 \mathrm{~m}$.

According to the results described above, those midHolocene dead coral heads exposed at low tide on the northwest coast of Hainan Island might suggest that the midHolocene sea level was higher than present.In addition, their different elevations may imply vertical crustal differential movements.

\section{Discussion}

\subsection{Implications for higher mid-Holocene sea level}

In the coral-reef regions of the South China coast (mainly around the Leizhou Peninsula and Hainan Island), several higher mid-Holocene sea-level traces have been recognized. For example, at Dengloujiao and Shuiweicun of the Leizhou Peninsula, the reef flats that formed during 6550-5300 a BP are now located $121.0-49.5 \mathrm{~cm}$ above the tidal datum, indicating the sea level at that time was 3-4 m higher than at present [19]. Furthermore, based on the TIMS (thermal ionization mass spectrometric) ages of the Porites samples collected from a reef terrace at Dengloujiao, several episodes of Holocene sea-level highstands were identified $[13,14]$. On the south coast of Hainan Island, data of elevations and ${ }^{14} \mathrm{C}$ ages of the in-situ fossil corals revealed that at least 4 high-sea-level episodes occurred during the Holocene, and the peak of the sea-level highstand could be dated be- 
tween 7.3 and 6.0 cal. ka BP [21]. Additionally, on the east coast of Hainan Island, a sea-level highstand of 2.0-2.2 m during 5.5-5.2 ka was found based on the TIMS ages and elevations of massive emerged Porites [22]. In addition, coral reefs in adjacent areas, such as Xisha Island, also showed indications of mid-Holocene higher sea levels $[8,16,40]$.

Data presented in this paper in combination with those gathered from other publications showed that massive dead corals in the investigated area mainly lived in the mid- to late-Holocene. Elevations of their dead tops relative to the present-day datum plane vary from 0.5 to $2.4 \mathrm{~m}$ (Figure 3 ). Therefore, the fossil corals in this area may predict a midHolocene sea-level highstand. To calculate the elevetion of the mid-Holocene sea level relative to the present sea level, the highest level of survival for massive corals must be documented first. According to relevant research, however, this "highest level" is not a fixed or uniform criterion. Different coral species or the same species growing in different seasons, regions or even biological-geomorphologic zones may have different upper growth limits $[1,10,41,42]$. Previous investigations of coral reefs in the South China Sea discovered that most massive Porites lived $1 \mathrm{~m}$ below the low-water spring tide level [14,19], and, accordingly, $1 \mathrm{~m}$ below the tidal datum was defined as the highest level of survival for Porites in application $[13,19]$. In contrast, the upper growth limit of flat corals mentioned by Zhang $[42,43]$ was the Mean Lower Low Water, which approximately corresponds to the mean low-water spring tide but is somewhat different from the low-water spring tide.

Provided that there is no top erosion of in-situ coral heads and using $1 \mathrm{~m}$ below the tidal datum as the upper limit for coral growth, the massive dead Porites of Paipu indicated the sea level between 5.7 and 3.0 cal. ka BP was 1.5-1.7 $\mathrm{m}$ above the present sea level, while at Shenjian and Eman, the mid-Holocene sea level height was estimated to be $2.3-3.4 \mathrm{~m}$ and $1.8-2.0 \mathrm{~m}$, respectively. This result coincides well with most previous studies $[8,19,22,44]$. Therefore, it can be concluded that the massive dead coral heads emerged in growth positions along the coast of northwestern Hainan Island suggest a higher mid-Holocene sea level under the assumption that $1 \mathrm{~m}$ below the tidal datum is the upper limit of coral growth. However, using the Mean Lower Low Water as the upper limit for coral growth, the Paipu sea level during 5.7-3.0 cal. ka BP was basically the same as present and only ranged between $-0.1-0.1 \mathrm{~m}$. This sea level height was calculated with reference to the Mean Lower Low Water of the Baimajin gauge station (0.6 above the tidal datum). At Shenjian and Eman, the mid-Holocene sea levels were 0.9-2.0 $\mathrm{m}$ and 0.4-0.6 m higher than present, respectively. The calculation was performed with reference to the Mean Lower Low Water of the Yangpu gauge station ( $0.4 \mathrm{~m}$ above the tidal datum).

Our analysis demonstrates that reconstructing the sea level using the same indicator but based on different criteria will have remarkably different results, which is why differ- ent scientists may obtain different sea level histories for the same area and, consequently, controversies about sea level changes inevitably arise. According to our research, the corals emerged on the volcanic coast do indicate a higher relative mid-Holocene sea level but are not necessary indicative of a higher eustatic sea level. Therefore, the occurrence of a higher relative mid-Holocene sea level on the volcanic coast was estimated to be the result of tectonic uplift related to volcanic activities, which suggests that tectonics should be taken into account when reconstructing the Holocene sea level for the South China coast and it might produce diametrically opposing results.

\subsection{Implications for vertical crustal movements}

Microatolls are among the most precise and useful diagnostic sea-level indicators found on coral reefs [41]. Using massive coral heads (which could also be defined as microatolls) exposed on the northwest coast of Hainan Island, midHolocene relative sea level data were obtained for this area, which varied from Paipu to Shenjian and Eman. Regardless of to which datum plane the upper limit of coral growth was defined, differences in the relative sea level change between these sites did not change sensitively with the calculations. For such a local area where the coast extends only tens of kilometers, significant differences in the relative sea level change must be the result of tectonic subsidence or uplift.

Between the non-volcanic coast in the south and the volcanic coast in the north, the differences in the relative sea level heights range from 0.3 to $2.1 \mathrm{~m}$. If erosion of the coral upper surface was taken into consideration, the deviation would increase because coral erosion was severer in the north than in the south. That is to say, the relative sea level of the volcanic coast would be much higher than that of the non-volcanic coast, impling that the volcanic coast, relative to the non-volcanic one, had been uplifted since the midHolocene. According to our previous research on the preHolocene marine strata outcropping along the coast of Shenjian [25], volcanic activities had led to crustal uplift since the Middle Pleistocene, causing some coastal zones to be turned to terrestric environments and the pre-Holocene marine sediments to be exposed to subaerial erosion. As volcanic activities decreased later in the Holocene, the intensity of tectonic deformation was remarkably reduced. Then, weathering, denudation and coastal erosion became the major geological processes in this area. However, under the influence of late-stage volcanism, moderate uplift of the crust continued, which finally led to the differences in elevations of the raised coral heads between the volcanic and the non-volcanic coasts. According to the data for modern vertical crustal deformation [45], the volcanic area is an uplift zone with rates of $0-1 \mathrm{~mm} / \mathrm{a}$, whereas the non-volcanic area is subsiding with rates ranging from 0 to $1 \mathrm{~mm} / \mathrm{a}$. Assuming that the crust of this area always deformed vertically at these rates, the total displacement of the north rela- 
tive to the south in the last 5000 years would be $0-10 \mathrm{~m}$. The discrepancies of $0.3-2.1 \mathrm{~m}$ in relative sea level heights estimated from the emerged coral heads are within the range, so it can be preliminarily concluded that the estimation is reasonable and reliable.

The significant variations in relative sea level data along the volcanic coast are also indicative of vertical tectonic displacements. For instance, the mid-Holocene relative sea level data between Shenjian and Eman exhibited a difference of $0.3-1.6 \mathrm{~m}$, indicating that volcanism at Shenjian has caused higher uplift. Additionally, on the residual islet near Shenjian, the dead corals, today in a 0.9-1.2 m higher position than those around them, suggested that the islet had been uplifted at least $1.2 \mathrm{~m}$ after the Middle Holocene. Based on an abundance of dark red-brown basalts scattered around, the residual islet was inferred to be a small volcano. Its last eruption might have occurred during the mid-Holocene, causing a relatively large uplift. As a result, intertidal microatolls with disc-shaped tops on the islet were paroxysmally exposed to the air, and the whole coral colonies soon died.

The coral samples from Shenjian were predominantly older in age as well as higher in elevation than those from Eman and Paipu. That means in-situ corals with higher upper surface would be older, indicating that coral growth might be in synchronism with tectonic uplift. According to this speculation, the corals at Shenjian died earlier because of the relatively rapid uplift, while corals at Eman and Paipu lived longer as the local crusts were slowly raised or the corals died as the eustatic sea level fell gradually since the Middle Holocene. In summary, differences in the recent elevations of in-situ fossil corals between the volcanic and the non-volcanic coasts were mainly caused by tectonic uplift.

\section{Conclusions}

Shallow-water corals are sensitive to environmental change, which makes fossil corals one of the most important records of past sea level changes and tectonic activities. This paper presents a comprehensive study on the chronology and elevation of fossil corals exposed on the coast of northwestern Hainan Island. The results show that the massive dead corals were mainly alive in the mid- to late-Holocene, with the mid-Holocene being a flourishing period. Using $1 \mathrm{~m}$ below the tidal datum as the upper limit of coral growth, the elevations of these dead corals predict a mid-Holocene sea level 1.5-3.4 m higher than the present level. However, the results changed remarkably when using the Mean Lower Low Water as the limit of upward coral growth. The mid-Holocene sea level at the non-volcanic coast was almost as high as the present level, whereas that at the volcanic coast was 0.4-2.0 $\mathrm{m}$ higher than present. Therefore, whether the emerged fossil corals on the coast of northwestern Hainan
Island indicate a mid-Holocene eustatic sea-level highstand is still uncertain and will require further investigation. What we can confirm now is that the emerged fossil corals on the volcanic coast truly predict a relative higher sea level. The differences in elevations of the dead coral tops, which point to differences in relative sea level heights, are interpreted as the result of differential tectonic uplift caused by volcanic activities.

Finally, according to the results presented above, the upper limit for coral upward growth must first be accurately established when using fossil corals to reconstruct past sea levels. In addition, vertical tectonics have to be taken into account as a significant factor in high-resolution sea level reconstruction, although the investigated area is located in a relatively "tectonically stable" region.

This work was supported by the National Natural Science Foundation of China (41006029 and 40976030) and the United Foundation of National Natural Science Foundation of China-Guangdong Natural Science Fund Committee (U0933006). The authors would like to thank the reviewers for their comments that help improve the manuscript.

1 Taylor F W, Jouannic C, Gilpin L, et al. Coral colonies as monitors of change in relative level of the land and sea: Applications to vertical tectonism. In: Proceedings of the 4th Int Coral Reef Symposium 2, 1982, 486-491

2 Bard E, Hamelin B, Fairbanks R G. U-Th ages obtained by mass spectrometry in corals from Barbados: Sea level during the past 130000 years. Nature, 1990, 346: 456-458

3 Yokoyama Y, Esat T M, Lambeck K. Last glacial sea-level change deduced from uplifted coral terraces of Huon Peninsula, Papua New Guinea. Quat Int, 2001, 83-85: 275-283

4 Sasaki K, Omura A, Murakami K, et al. Interstadial coral reef terraces and relative sea-level changes during marine oxygen isotope stages 3-4, Kikai Island, central Ryukyus, Japan. Quat Int, 2004, 120: 51-64

5 Banerjee P K. Holocene and Late Pleistocene relative sea level fluctuations along the east coast of India. Mar Geol, 2000, 167: 243-260

6 Bezerra F H R, Barreto A M F, Suguio K. Holocene sea-level history on the Rio Grande do Norte State coast, Brazil. Mar Geol, 2003, 196: 73-89

7 Woodroffe C, Mclean R. Microatolls and recent sea level change on coral atolls. Nature, 1990, 344: 531-534

8 Nie B F. Sea-level changes of the South China Sea in the past 5000 years (in Chinese). Quat Sci,1996, 19: 80-87

9 Taylor F W, Jouannic C, Bloom A L. Quaternary uplift of the Torres Islands, northern New Hebrides frontal arc: Comparison with Santo and Malekula Islands, central New Hebrides frontal arc. J Geol, 1985, 93: 419-438

10 Taylor F W, Frohlich C, Lecolle J, et al. Analysis of partially emerged corals and reef terraces comparison of contemporary coseismic and nonseismic with Quaternary vertical movements. J Geophys Res, 1987, 92: 4905-4933

11 Nunn P D, Ollier C, Hope G, et al. Late Quaternary sea-level and tectonic changes in northeast Fiji. Mar Geol, 2002, 187: 299-311

12 Pirazzoli P A, Reyss J L, Fontugne M, et al. Quaternary coral-reef terraces from Kish and Qeshm Islands, Persian Gulf: New radiometric ages and tectonic implications. Quat Int, 2004, 120: 15-27

13 Zhao J X, Yu K F. Timing of Holocene sea-level highstands by mass spectro-metric U-series ages of a coral reef from Leizhou Peninsula, South China Sea. Chin Sci Bull, 2002, 47: 348-352

14 Yu K F, Zhong J L, Zhao J X, et al. Biological-geomorphological zones in a coral reef area at southwest Leizhou Peninsula unveil multiple sea level high-stands in the Holocene (in Chinese). Mar Geol 
Quat Geol, 2002, 22: 27-33

15 Peng Z C, He X X, Luo X Z, et al. Thermal Ionization Mass Spectrometry (TIMS)-U-Series ages of corals from the South China Sea and Holocene high sea level. Chin J Geochem, 2003, 22: 133-139

16 Ma Z B, Xiao J L, Zhao X T, et al. Precise U-series dating of coral reefs from the South China Sea and the high sea level during the Holocene. J Coast Res, 2003, 19: 296-303

17 Yim W W-S, Huang G. Middle Holocene higher sea-level indicators from the south China coast. Mar Geol 2002, 182: 225-230

18 Zong Y Q. Mid-Holocene sea-level highstand along the Southeast Coast of China. Quat Int, 2004, 117: 55-67

19 Nie B F, Chen T G, Liang M T, et al. Coral reefs in the Leizhou Peninsular and Holocene higher sea level (in Chinese). Chin Sci Bull (Chin Ver), 1997, 42: 511-514

20 Yu K F, Zhao J X, Done T, et al. Microatoll record for large century-scale sea-level fluctuations in the mid-Holocene. Quat Res, 2009, 71: 354-360

21 Huang D Y, Shi Q, Zhang Y C. Coral reef and high sea level at Luhuitou, Hainan Island during the Holocene (in Chinese). Mar Geol Quat Geol, 2005, 25: 1-7

22 Shi X J, Yu K F, Chen T G, et al. Mid- to late-Holocene sea level highstands: Evidence from fringing coral reefs at Qionghai, Hainan Island (in Chinese). Mar Geol Quat Geol, 2008, 28: 1-9

23 Zhou D, Ru K, Chen H Z. Kinematics of Cenozoic extension on the South China Sea continental margin and its implications for the tectonic evolution of the region. Tectonophysics, 1995, 251: 161-177

24 Ho K S, Chen J C, Juang W S. Geochronology and geochemistry of late Cenozoic basalts from the Leiqiong area, southern China. J Asian Earth Sci, 2000, 18: 307-324

25 Yao Y T, Zhan W H, Sun J L, et al. Correlation and implication of marine strata around Lianhua Mountain in the northwestern Hainan Island (in Chinese). Mar Geol Quat Geol, 2009, 29: 43-51

26 Wang Y, Zhou L F. The volcanic coast in the area of northewest Hainan Island (in Chinese). Acta Geogr Sin, 1990, 45: 322-330

27 Yao Y T, Harff J, Meyer M, et al. Reconstruction of paleocoastlines for the northwestern South China Sea since the Last Glacial Maximum. Sci China Ser D-Earth Sci, 2009, 52: 1127-1136

28 Zhao X T, Zhang J W, Li G Y. Development of the Holocene coral reefs along the southern coast of Hainan Island (in Chinese). Chin J Geol, 1983, 18: 150-159

29 Zhou S G, Ye Y G, Liu X B. Geochemical characteristics of REE in coral reef of sanya-3-well and its paleoclimatic signification (in Chinese). Mar Geol Quat Geol, 1997, 17: 103-110

30 Lv B Q, Wang H G, Oba T, et al. Monsoon climatic record of oxygen and carbon isotopic data from Porites lutea in Shalao fringing reef, Hainan Island (in Chinese). Geochimica, 2002, 31: 315-320

31 He X X, Liu D Y, Peng Z C, et al. Monthly sea surface temperature records reconstructed by $\delta^{18} \mathrm{O}$ of reef-building coral in the east of Hainan Island, South China Sea. Sci China Ser B-Chem, 2002, 45(Supp I): 130-136

32 Huang D Y, Shi Q, Zhang Y C, et al. The ${ }^{14} \mathrm{C}$ ages and evolvement of coral reef in Luhuitou Peninsula, Hainan Island (in Chinese). Mar Sci Bull, 2004, 23: 31-37

33 Yu K F, Zhao J X, Lawrence M G, et al. Timing and duration of growth hiatuses in mid Holocene massive Porites corals from the northern South China Sea. J Quat Sci, 2010, 25: 1284-1292

34 Huang J S. Coral reefs on the southern and western coasts of the Hainan Island. Chin Sci Bull, 1965, 10: 85-87

35 Lü B Q, Wang G Z, Quan S Q. The characteristics of fringing reefs of Hainan Island (in Chinese). Geograph Res, 1984, 3: 1-16

36 Qiu S J. Reef development and sea level changes. In: International Geological Correlation Programme. Project 200. China Working Group, ed. Sea Level Changes in China (in Chinese). Beijing: China Ocean Press, 1986. 205-212

37 Quan S Q, Wang G Z, Lü B Q. The recent corbonate sedimentary facies and sedimentation of the muddy water in the Paipu fringing coral reef, Hainan Island (in Chinese). Oceanol Limnol Sin, 1988, 19: 179-186

38 Zhang M S, Liu J, Li H, et al. Basic characteristics and formation time of peripheral coral reefs in Hainan Island (in Chinese). Mar Geol Quat Geol, 1990, 10: 25-43

39 Zhao H T, Wang L R, Song C J, et al. Features of fringing reef at Dengloujiao, Leizhou Peninsula (in Chinese). Mar Geol Quat Geol, 2002, 22: 35-40

40 Ma Z B, Xia M, Zhang C H, et al. Research on high-precision TIMS U-series dating of the Holocene coral reefs in the South China Sea (in Chinese). Chin Sci Bull (Chin Ver), 1998, 42: 2225-2229

41 Smithers S G, Woodroffe C D. Microatolls as sea-level indicators on a mid-ocean atoll. Mar Geol, 2000, 168: 61-78

42 Zhang Q M. On biogeomorphology of Luhuitou fringing reef of Sanya City, Hainan Island, China. Chin Sci Bull, 2001, 46(Supp): 97-102

43 Zhang Q M. Coastal bio-geomorphologic zonation of coral reefs and mangroves and tide level control. J Coastal Res, 2004, 43: 202-211

44 Huang Z G, Zhang W Q. On elevation differentiation of the Holocene high sea level relics in the South China Sea area (in Chinese). J Oceanogr Taiwan Strait, 2005, 24: 228-235

45 Wei B L. Characteristics of Seismic Activities on the Southeast Coast of China (in Chinese). Beijing: Seismological Press, 2001

Open Access This article is distributed under the terms of the Creative Commons Attribution License which permits any use, distribution, and reproduction in any medium, provided the original author(s) and source are credited. 